\title{
Nursing team communication in a medical ward
}

\author{
A comunicação da equipe de enfermagem de uma enfermaria de clínica médica \\ Comunicación del grupo de enfermeros de una enfermería de clínica médica
}

\section{Priscilla Valladares Broca', Márcia de Assunção Ferreira'}

' Universidade Federal do Rio de Janeiro, Anna Nery Nursing School, Fundamental Nursing Department. Rio de Janeiro, Brazil.

How to cite this article:

Broca PV, Ferreira MA. Nursing team communication in a medical ward. Rev Bras Enferm [Internet]. 2018;71(3):951-8. DOI: http://dx.doi.org/10.1590/0034-7167-2017-0208

Submission: 03-31-2017 Approval: 05-16-2017

\section{ABSTRACT}

Objective: To describe the essential elements that make the nursing team communication process effective, and to analyze such elements in the light of two main theorists, Berlo and King. Method: This is a qualitative study of assistant convergent research approach. The data production technique was the semi-structured interview, with 25 nursing professionals from a public hospital. Data were analyzed with thematic content techniques. Results: The main element of consolidation of the communication process and interpersonal relationship, with consequent interaction, is the dialogue, which is guided by emotions, feelings, and team integration. Conclusion: The communication process and the interpersonal relationship reach their objectives and the reciprocal understanding expected when there is effective dialogue, validated by the source and receiver of the processes, with consequent interaction.

Descriptors: Communication; Nursing Team; Nursing Care; Interpersonal Relationships; Nursing Theory.

\section{RESUMO}

Objetivo: Descrever os elementos essenciais que tornam o processo de comunicação de uma equipe de enfermagem efetivo e analisar tais elementos à luz de dois teóricos principais, Berlo e King. Método: De natureza qualitativa, foi aplicado o método da pesquisa convergente-assistencial. A técnica de produção dos dados foi a entrevista semiestruturada, com 25 profissionais de enfermagem de um hospital público. Aos dados foram aplicadas as técnicas de análise de conteúdo temática. Resultados: O principal elemento de consolidação do processo de comunicação e do relacionamento interpessoal, com consequente interação, é o diálogo, sendo norteado por emoções, sentimentos e integração da equipe. Conclusão: O processo de comunicação e o relacionamento interpessoal alcançam seus objetivos e o entendimento recíproco esperado quando há diálogo efetivo, validado pela fonte e receptor dos processos, com consequente interação.

Descritores: Comunicação; Equipe de Enfermagem; Cuidados de Enfermagem; Relações Interpessoais; Teoria de Enfermagem.

\section{RESUMEN}

Objetivo: Describir los elementos esenciales que hacen que el proceso de un equipo de enfermería sea efectivo, y analizar tales elementos a la luz de dos teóricos relevantes, Berlo y King. Método: De naturaleza cualitativa, fue aplicado el método de la investigación convergente-asistencial. Datos producidos a partir de técnica de entrevista semiestructurada, con 25 profesionales de enfermería de un hospital público. Los datos fueron estudiados por análisis de contenido temático. Resultados: El principal elemento de consolidación del proceso de comunicación y de las relaciones interpersonales, con la consecuente interacción, se trata del diálogo, que es orientado por emociones, sentimientos e integración del equipo. Conclusión: El proceso de comunicación y las relaciones interpersonales alcanzan sus objetivos y el entendimiento recíproco esperado cuando existe diálogo efectivo, validado por la fuente y el receptor de los procesos, con la consecuente interacción.

Descriptores: Comunicación; Grupo de Enfermería; Atención de Enfermería; Relaciones Interpersonales; Teoría de la Enfermería. 


\section{INTRODUCTION}

Nursing care is the point of departure and arrival of the interpersonal relationship among the professionals of the nursing team. This relationship is based on the communication process, with interaction as its objective, to understand and to be understood, in order to achieve the goal proposed when communication was initiated ${ }^{(1)}$.

The communication process is complex, dynamic, flexible, presenting structured elements that influence negatively or positively, aiming at the understanding among the individuals. To occur, individuals need to be willing and attentive to the communicative act as a whole, because it contains what is spoken and written, as well as what is observed and perceived.

Thus, the process of communication can be expressed through the intentional relationship with others. That is to say, this relationship can be characterized by the interaction between process partners to share, transmit, announce, exchange, assemble, and connect an idea, which characterizes communication as essentially relational/ interactive. Based on this idea, the communication process cannot be understood as merely informational, but is also based on human relations. What characterizes an interaction has an involvement with the perception of feelings, of verbal and non-verbal communication, as well as with individuals' behavior and personality ${ }^{(2)}$.

Through the communication process and its exercise, activities such as teaching, ideas are exchanged and confronted. Sharing of thoughts and information is developed, with the purpose of conveying and submitting information, tasks, and opinions to the discussion. This process can be characterized by dialogue, through which two or more individuals exchange messages. However, the process is not restricted to speech, because there is hearing and writing; hand, feet, or body gestures; facial expressions; and drawings, among other factors that impact communication.

These elements demonstrate the importance and complexity of a communication process, and consequently of an interpersonal relationship, with the aim of human interaction. This relationship can be used as a facilitator of the practice of humanization $^{(1)}$, because it can help nursing professionals to share effective teamwork that provides opportunities for participation, sharing, and seeking solutions to the problems that arise mainly for nurses, which lie in the field of human interaction. In addition, communication is necessary to provide nursing care, and is dependent on relationships established among nursing professional $\mathrm{s}^{(3)}$.

Nursing can have as a characteristic the ability to know how to listen, to observe, to speak with caution. Therefore, one can carefully interpret and analyze the message before making any decision or taking an action. Thus, it is important to select the style of communication, that is, to choose the one that best suits the nature, confidentiality, sensitivity, and possible impact of the content of the message on the recipient ${ }^{(4)}$. It is imperative to know how to best use the essential elements that make up the communication process of the nursing team so that it is effective, and professionals can deal with the strengths and limitations, adjusting the content of communication, and the way communication takes place.

\section{OBJECTIVE}

To describe the essential elements, according to the nursing team, that make the communication process effective, and to analyze these elements in the light of two main theorists, Berlo and King.

\section{METHOD}

\section{Ethical aspects}

The research was approved by the Research Ethics Committee of HUCFF/UFRJ. The participants' rights were respected in accordance with Resolution 466/12 of the National Health Council/Ministry of Health. Thus, the identification of the subjects was done by alphanumeric codes, with the nurses identified by the letter $E$, and the nursing technicians by the initials $\mathrm{TE}$, followed by the sequential number of the interview.

\section{Theoretical frameworks}

Berlo $^{(5)}$ presents a model of communication process with elements of how individuals communicate, what factors make up the communication process, and what the role of language is in human behavior. In addition, the complex nature of the model proposed to explain the communication process analyzes people's behavior, the relationship between the speaker and the listener, in order to try to identify and describe the factors that positively and negatively influence the communication process and its results, seeking ways to try to increase the understanding and effectiveness of communication.

In the author' s model, the communication process has the source, the encoder, the message, the channel, the decoder, and the recipient, which have some factors influencing them ${ }^{(5)}$. Thus, it instructs to identify and describe the factors influencing the communication process, to seek ways to make the process more understandable and, especially, to observe how they can aid in its effectiveness, but without simplifying it.

$\mathrm{King}^{(6)}$ reports that human beings are open systems in constant interaction with the environment. He proposes a conceptual structure of interactive systems, which are the personal, interpersonal, and social systems. The personal system can be understood as the position of the individual in the environment. The interpersonal system refers to when individuals interact with each other to form pairs, trios, or small and large groups. The social system is understood when individuals see the need to form organizations that make up communities or societies due to special interests and needs.

In systems, there is reference to the multiple interactions among individuals that can be developed through verbal and non-verbal communication ${ }^{(6)}$, which indicates a characterization of interpersonal relationships and of the communication process, and that need to walk together to obtain a positive response of this process. In this sense, it is added that communication can be characterized as a structure of symbols and signs that impose order and meaning to human interactions. Thus, through interaction, human beings influence the way of acting and thinking of the other. That is, a level of interdependence is assumed ${ }^{(5-6)}$. 
These theoretical frameworks have been chosen because they have studied communication and human interactionthat is, because they focused on the purpose of communication, how it can be used, what elements make it up, and which factors may negatively or positively influence the communication process and interpersonal relationship. Therefore, these studies can contribute to help the nursing team to better face the difficulties involved in communication.

\section{Study type}

This research is qualitative, characterized as assistant convergent. Assistant convergent research (ACR) requires the active participation of the research subjects, with the aim of making changes and/or introducing innovations in healthcare practices, because it involves the researcher and the research participants in a relationship of mutual cooperation ${ }^{(7)}$. The method allows a close relationship between the know-how-tothink and the know-how-to-do because the context of the care practice indicates innovations and alternatives to minimize or solve problems and health professionals' daily difficulties.

The implementation of ACR takes place through the following phases: the conception represents the choice of the theme, the orientation of the guiding question, the definition of the objectives of the research, and the literature review. The instrumentation refers to the methodological procedures. Scrutiny includes the collection and recording of data. Analysis and interpretation consists of subjectively examining the data, making associations and variations of the information found in the process of collection ${ }^{(7)}$.

In order to research the communication process in the nursing team, it is necessary to raise the awareness of all those involved in the communication process, and to get their commitment to this process. For this, it is necessary to expose the objective and the importance of being integrated in the communication process to all those involved. This procedure was possible with the use of ACR, because this method is based on a dynamic process, that is, the distinct steps do not necessarily occur in a rigid sequence, but can occur concomitantly ${ }^{(8)}$.

\section{Methodological procedures}

\section{Study setting}

The research was carried out in the medical clinic department of a public university and federal hospital in the city of Rio de Janeiro. The scenario hospital focuses its activities on the link between population assistance, education, and scientific research. Its actions are in constant integration with the social function, in which ethical, humanistic, and quality care is valued so as to be in harmony with the Unified Health System (SUS).

Regarding care, the hospital provides specialized and highly complex care in the emergency department, outpatient clinics, admission departments (in internal medicine, surgical, and intensive care units), and in the surgical center in the most diverse surgeries, which characterizes the multidisciplinarity of the hospital.

\section{Data source}

The study group consisted of 25 nursing professionals, with five nurses and 20 nursing technicians. These professionals formed the teams that actively worked in the study scenario for at least six months. The inclusion criterion was to be working in care at the time of data collection. Nurses who were not working in the care process due to vacation or work leave were excluded.

\section{Data collection}

Data collection was carried out between October and November of 2012, with the technique of data production being a semistructured interview, based on a script with open questions. The interview meeting was characterized by a moment of individual conversations (the researcher and one more professional), at the most favorable time for the professional, that is, according to the availability of the nursing professionals during a working day. The researcher, during these meetings, had the objective of, at the same time, developing the research and the social and personal growth of the participants, based on the phase of convergence of the method.

Before the individual meetings, the researcher was immersed in the scenario that began in August 2012. This approach occurred so that the researcher could integrate with the dynamics of the sectors, and know the professionals' routine of care and work, in order to try to interfere as little as possible in the care provided to patients during the production of the data.

\section{Data analysis}

The verbal data from the meetings were recorded in electronic format, and fully transcribed by the researcher. The thematic content analysis technique ${ }^{(9)}$ was applied to the corpus of this research. These data were separated thematically, and were identified and grouped according to the presence or frequency of occurrences of themes arising from the professionals' speeches. Based on these occurrences, groups were formed according to the theme of greater frequency, also considering the co-occurrence of themes in the speeches, with the following categories: effective dialogue/something fundamental; and feelings shared as a form of interaction. These categories were discussed based on the concepts and definitions of theoretical references.

\section{RESULTS}

\section{The effective dialogue: something fundamental}

The communication elements used and their combinations can be determined by the situation and the context in which the individual is. However, not using all the elements combined may not achieve the goal expected when the communication process started. From this direction, nursing professionals reported that the main element to consolidate a communication process and an interpersonal relationship, with consequent interaction, is dialogue.

A good dialogue is necessary ... the person who explains well ... I do a necropsy course ... my teacher is great ... I think she has good communication ... because she says ... I understand everything, things I haven't studied, only her explanation makes me understand, I think this is good communication. (TE11)

Fundamental is the dialogue, right? Otherwise you can't establish a relationship, say what you want and what you do 
not want! Got it? Even for you to have a feedback from your team, you know? So I think this is fundamental! (E1)

What do we need? Well, a lot of conversation, a lot of dialogue for the work to flow. And ... essential for the work ... for the work to be done. (E5)

The dialogue is also presented as an important instrument to make the work of the nursing team flow in the best way possible. With this, the professionals can more easily provide quality customer service, as evidenced by E1 and E5's speeches. Thus, because the nursing team has a common interest and the same objective, which is nursing care, the dialogue can be used as a great facilitator in this relationship.

It should be noted that the source (the one initiating the communication process), in addition to having an objective to communicate, needs to have an audience. The source needs the receiver to pay attention to what is being communicated. In addition, attention must be extended to the source when it becomes the receiver, because the audience must be reciprocal. It is ineffective for the source to want full attention when sharing the message if, when it becomes a receiver, it does not act receptively and does not offer the right audience. In this sense, the unit of record below exemplifies these difficulties in having a dialogue, or even lack of it.

[...] We don't talk to our colleagues. You come in and out. We went through a situation here, our colleague felt bad, is hospitalized and her condition is serious, and nobody, like .... she was in pain and nobody cared and nobody saw. If she sat down and talked to someone, it was possible to see that she was feeling something! We don't do it! We spent 12 hours with her at our side and nobody noticed. It went unnoticed! She started to feel bad here! (TE6)

In the statement above, non-verbal communication was not valued. TE6 stated that someone on the team noticed or perceived that the peer was not feeling well. As the colleague did not inform anyone verbally about what she was feeling, they only identified her condition when the professional had a more severe clinical change.

\section{Feelings shared as a way of interacting}

One of the goals, if not the main one, of a communication process among human beings is interaction. According to the return of this interaction, the source can change the message and the channel used. Based on this, nursing professionals reported that in order to have an effective and validated communication process and a good interpersonal relationship it is necessary to establish a relationship of trust, respect, sincerity, honesty, and integration among team members, as can be seen in the following recorded units.

Honesty, you know? It is ... always telling the truth, not lying, it's ... interaction with the nursing team. (TE15)

I think that what is important in communication between two human beings is sincerity, I think that, when there is sincerity, the communication is good. Sincerity, truth in the words. I think it is important, because just communicating with another person you can make a friend. (TE12)

Well ... I think the main thing is respect, right? Respect, trust, right? Partnership, because we are ... we can't be alone, there are times when you need help, especially in our profession, right?... Sometimes I can't punch this access here. It's not that you're a bad professional; sometimes you're not on a good day. Then you go and call the colleague and he goes on the first time. You have to have this partnership, of one helping the other, right? (TE4)

Know how to work as a team. If we work as a team the agent will have a good interaction and respect as well. I think it ends up having a connection there. I think they complement each other. I think we have to know how to work in a team. (E 4)

To wish for respect, sincerity, and honesty in the process of communication is to see and understand that the other needs to be recognized as an individual with feelings, emotions, sensitivity, and dignity. Mainly, it is about not wanting to do with the other something that you do not want them to do with you. It is also necessary to exercise such behavior, regardless of who is the source, even when it comes from someone with lower knowledge compared to the more experienced professional.

\section{DISCUSSION}

The act of communicating consists of an event with specific ingredients, in which one acts on the other and each one influences all the others ${ }^{(5)}$. It can be characterized as a structure of symbols and signs that imposes order and meaning on human interactions ${ }^{(6)}$. In this way, using and identifying all of the (verbal and nonverbal) elements, which together structure the communication process, is important because one complements the other. In addition, it is possible to influence those who communicate with greater precision and, consequently, the objective of the communication process becomes effective and validated.

With this effectiveness, interaction is achieved, and is an important element for care, so that it contributes to identify the client's needs in a participative and integrative way, providing satisfaction of both of them ${ }^{(10)}$. Thus, it is necessary to extend this relationship to the members of the nursing team, because when the interaction and the communication process do not satisfy the professionals, there is loss of friendship, leading some of them to experience great dissatisfaction, sadness, and pain in their work ${ }^{(5)}$.

Dialogue can be understood as the transmission of meanings in order to identify whether the interlocutors have the same idea-that is, if it is based on the principle of supporting collaboration with the aim of creating a mutually shared understanding ${ }^{(11)}$. Thus, dialogue can be characterized as a way for the individual to express him/herself before the other, showing his/ her point of view, with the intention of transmitting a thought, idea, or information, so that together they achieve their goals.

Thus, dialogue is a means by which an end or result is achieved, and enables individuals to convey, exchange, or 
share goals and limitations, and recognize mistakes and successes. All of this understanding can be achieved when language is used to portray the reality in which one lives, and to represent what one thinks. This way, it acts as a structuring element of human interaction.

The main function of language in society is to facilitate cooperation and interaction among individuals as the main facilitator of the development of individuals who transmit their experiences and thoughts ${ }^{(6)}$. This can provide a better relationship between individuals, where this sharing of knowledge and experience helps in understanding the meaning of words according to each person's worldview. If the interlocutors know each other or trust each other, sometimes only through non-verbal signals, they are able to reach a conclusion and understanding faster, with positive results ${ }^{(2)}$.

For verbal communication to have meaning, it is necessary that the interlocutors involved in the process have a common interest and at least similar objectives ${ }^{(5-6)}$. Thus, to be able to dominate a dialogue is to gather and transmit what is thought in the best way possible, and lead to reflection on what is being talked about in order to reach an effective communication process. Thus, the importance of thinking and being conscious when expressing verbally is highlighted, because when a word is said it is not possible to take it back. Sometimes it can result in an ineffective communicative act.

A source who has linguistic ease has greater ability to influence the other by being able to clearly state what he or she wants to communicate. It is necessary that there be a relation between what is being said orally and the behavior and attitudes manifested by the individual ${ }^{(2)}$. In addition, language has a different meaning for each individual, because although they know the linguistic concept of words, people impose meaning on them, which allows for a range of interpretations ${ }^{(6)}$. Thus, if the source has insufficient language, making interpretations difficult, it may limit the exposure of ideas, thoughts, and feelings, and present an obstacle to achieving the goal of communication.

For a communication process to achieve its goal, either focused only on the oral means of communication or not, it is necessary to have a receiver present, sufficiently integrated to communication, to actively listen to what is being said. Listening is an important element of communication that requires, from the interlocutors, active participation in the oral exchange, because not actively participating in this process brings the risk of not being able to contest shared information $^{(6)}$. How to question something about a dialogue that has not been given due attention? Thus, active listening can provide a path to new knowledge and thought, as well as opening the field for the perception of new information.

In addition, individuals do not usually focus on the behavior of the communicator, but only on the message that is being conveyed, in order to determine, identify, and pay attention to the communication goal ${ }^{(5)}$. This may mean that the individual is generally concerned with the message itself (in this case the verbal message) rather than with its quality and the context in which that process is involved. Especially for a team that has its work based on human relationships, the caregiver and the person cared for need to perceive, observe, identify, and understand what is involved in the communication process in addition to the speech.

Such attitudes can be classified into positive communication behaviors, such as making eye contact, asking open-ended questions, greeting each other by name or touch, and using gestures, expressions, and notes. There are also negative communication behaviors, such as the lack of eye contact for complete sharing, too rapid speech, and lack of attention ${ }^{(12)}$. In this way, with the practice of positive behaviors, it becomes easier to get the attention of the other, and to avoid being ignored.

When a communication process is established, prediction by the process interlocutors regarding the way in which the message will be answered, the time of interaction, the tolerance to listen rather than speak, the ease of expression, the observation of body expressions and the determination of social relations $^{(5)}$ is involved. In addition, the feelings, the exposure, and the manifestation or tendency to sensitivity, sentimentality, or emotions by the participants in the process can be included as a prediction.

Therefore, respecting, trusting, and being honest and sincere are related to the feelings that surround the relationships established among individuals. The human being is surrounded by many feelings and emotions that lead him/her to a way of understanding, perceiving, identifying, and grieving about the sharing of thoughts, ideas, attitudes, information, and knowledge.

To wish respect in the communication process is to see and understand that the other needs to be recognized as an individual endowed with feelings and emotions and, mainly, it is to exercise empathy, that is, not to do to the other something that you do not want for you. Those who are sincere express themselves, or at least intend not to deceive the other or to disguise feelings, information, and ideas or any sincere action. This is the individual who does not hide what he/she thinks and feels, and with that, he/she demonstrates him/herself frankly, with no dissimulation or masking. Bringing honesty to the communication process increases the trust between the interlocutors, thus establishing a relational bond that can help in the effectiveness and validity of the process. When a trustworthy relationship is established among individuals, it is believed that body expressions and speech are true; credit is given, and expectations are created about this exchange and sharing of information, feelings and emotions.

Communication should be carried out in an atmosphere of mutual respect and desire for understanding. Therefore, the interlocutors of the process perceive each other, make judgments of each other, present doubts, and react to the perception of each act and verbal or non-verbal expression of others ${ }^{(6)}$. This may correspond to what one needs to have in a communication process and in a personal relationship demonstrated by the nursing team, because there are human feelings and emotions involved, with the need for respect, sincerity, trust, and honesty.

To use these elements is also important when interacting with clients and their families. As presented in research on family caregivers, communication in which there is a relationship of trust, respect, sensitivity, and coherent use of words 
allowed the subjects to feel like a member of the nursing team, and to get clearer explanations ${ }^{(13)}$. Thus, these attributes can function as mediators of the interaction among the participants in the care, essential to reach humanization in care.

Thus, when establishing a communication process, there are expectations about the behavior of the source and the recipient, which influences the message regarding the treatment and self-image ${ }^{(5)}$, which brings the concept of empathy to the communication process in the nursing team. Empathy is understood as the ability to project oneself into the personalities of other people, so that individuals can directly observe their own physical behavior, and symbolically relate this behavior to their psychological states, feelings, thoughts and emotions ${ }^{(5)}$. Thus, it forms interpretations for their behavior.

The individual compares his/her own behavior that reflects a state with a similar behavior observed in the other ${ }^{(5)}$. With empathy, the individual can identify him/herself with the other person regarding his/her feelings. That is, it is possible to assume the feelings that the other is feeling. Therefore, to have confidence, sincerity, and respect in the communication process, the interlocutors need to have had previous experience with such sensations.

Nursing professionals indicated these elements as necessary to be part of the communication process, and the interactive relationship, because they are feelings that they share with each other and consequently would like to receive. Thus, empathy comes as a way of enabling individuals to project themselves into the feelings and actions of the other, and thereby give an affective response that is appropriate to the situation of the other person, not to the situation itself. Above all, they should be responses based on respect, sincerity and honesty.

With this, the interlocutors involved in the process can establish a subject-subject relationship, different from the relationship of information injections, in which both share the same feelings, thoughts, and emotions because they integrate empathy into communicational relationships. Thus, these elements can be considered attributes of nursing care, along with love, solidarity, compassion, zeal, and others ${ }^{(10)}$.

When there is a process of communication with a large number of interlocutors, it is necessary to consider one individual involved in the process at a time, because empathy can be decreased when there are a lot of people ${ }^{(5)}$. Consequently, there may be difficulty in establishing effectiveness in the communication process. Therefore, it is important to consider each member of the nursing team as a unique being, with his/ her limitations and positive and negative attitudes and, thus, to obtain integration among nursing professionals.

When there is less contact or interaction among individuals, the communication process and the interpersonal relationship becomes more difficult ${ }^{(5)}$. As can be exemplified by the nursing team, the existence of many tasks to be fulfilled, as well as the lack of sufficient human and material resources to provide quality care, lead to a context that is unfavorable to interactions and communicative acts. Thus, when there is no motivation, the communication process is often not perceived, and individuals do not make an effort to utilize it ${ }^{(5)}$.

When teamwork is in effect, moments of conflicts can be interpreted as unfavorable and inconvenient. However, they are situations inherent to the dynamics of teamwork that provide the possibility for professional growth, if they are worked in a coherent way, as this facilitates coping with communication, information, and dialogue barriers, in addition to providing more collaborative and supportive assistance ${ }^{(14)}$. This avoids devalued care that does not meet the real needs of clients and professionals ${ }^{(15)}$.

When nursing professionals come to see themselves as a team, in an integrated way, it becomes possible to actively participate in care, creating a movement of changes towards a goal ${ }^{(6)}$. It is inevitable to observe the importance of good interaction and communication among professionals towards the client, because it is crucial to protect patients from medication errors, falls, and other complications ${ }^{(16)}$. With this, the view of union and perception of each other can create an idea of equality, with the obtainment of support among the members of the nursing team.

Therefore, assistance was converged with nursing professionals so that they became aware of the importance of nonverbal communication, and how to best use and recognize it in a dialogue. In addition, the instruction included that the recipient's full attention should be requested so that no misinterpretations of shared information would arise. In situations where team members communicate with someone but no answer is obtained, non-verbal communication should be used, such as touch, to draw the person's attention in order for him/ her to fully participate in the conversation, as well as to receive respect, honesty, and sincerity, feelings that should be provided to the other in order that they will be received back.

The communication process, in addition to being an effective and validated interactive relationship, can give nursing professionals a perception that they are integrated and united, as part of a whole (team + nursing care), where each one understands that he/she is part of the same whole, with different functions and a single purpose. Being physically present is not sufficient, because it is necessary to be present in thought, emotions, feelings, and actions before the act of caring for the client.

In addition, the intervention was made so as to lead professionals to reflect that nursing is not performed by a single person, because it is performed as joint work. In this way, care is best provided and the needs and appropriate treatment for the client are most efficiently met. When noticing a peer who is not working with a team, who does not have a good interaction, it is recommended to help him/her to become aware of the benefits of working in cooperation and exercising fellowship to provide nursing care.

\section{Study limitations}

The use of the single specific scenario of a University Hospital in Rio de Janeiro is indicated as a limitation of the study. Thus, the expansion of the research to other fields of action may contribute to understanding the reality of communication within the nursing team and for future research in the area.

\section{Contributions to the Nursing area}

This study's aim was to strengthen and deepen cooperation, companionship, and teamwork, and to improve the communication process and the interaction among nursing professionals, in order to try to change the reality of nursing care, 
thinking about the professional and taking as a consequence nursing care based on the practice of humanization and patient safety. In addition, its aim was to demonstrate the application of a nursing theory, as a theoretical and practical reference and, with that, to contribute to the nursing to establish itself as science and art.

\section{CONCLUSION}

For the communication process, and consequently good interpersonal relationships to take place, some elements are necessary. These elements are crucial for the communication process to be effective and to achieve its goal, because the human being depends on this relationship to live in society and thus share information, feelings (such as respect and trust), values, experiences, and ideas, and to interact, in addition to being able to understand and to be understood in the process.

It is concluded that the communication process and effective interpersonal relationship reach their objectives and a reciprocal understanding expected when there is effective dialogue, and validated by the process source and recipient, with consequent interaction. Moreover, it provides better fluidity in teamwork and consequently in nursing care. However, it is necessary to have an audience because, without proper attention, effective dialogue, the communicative act, and the interpersonal relationship are impaired.

For the nursing team, dialogue and interaction need to be guided by feelings and affectivity, with respect, sincerity, honesty, and trust to achieve effectiveness being essential. Thus, it becomes possible to try to understand the other in his/her peculiarities, and to facilitate the process. In order to achieve such relationships, professionals bring empathy as a way of trying to project themselves into the other and so presume the feelings of the other, aiding in relationships. For this, union and teamwork can be an important element that facilitates the effectiveness of the process.

It is important to emphasize that, in order to achieve the effectiveness of these relationships, it is necessary to remember the importance of non-verbal communication. Non-verbal communication is part of effective dialogue, because through it there is a complementarity of speech. In addition, it is also possible to identify contradictions regarding what is being said and, thus, to try an intervention to achieve the goal and the objective of communication and interaction.

\section{REFERENCES}

1. Broca PV, Ferreira MA. Equipe de enfermagem e comunicação: contribuições para o cuidado de enfermagem. Rev Bras Enferm [Internet]. 2012 [cited 2016 Apr 4];65(1):97-103. Available from: http://dx.doi.org/10.1590/S0034-71672012000100014

2. Scholl W. The socio-emotional basis of human interaction and communication: how we construct our social world. Soc Sci Inform[Internet]. 2013 [cited 2016 Apr 4];52(1)3-33. Available from: http://dx.doi.org/10.1177/0539018412466607

3. Cowin LS, Eagar SC. Collegial relationship breakdown: a qualitative exploration of nurses in acute care settings. Collegian [Internet]. 2013 [cited 2016 Apr 4];20(2):115-21. Available from: http://www.ncbi.nlm.nih.gov/pubmed/23898600

4. Rosenberg MC. Editorial: communication style makes a difference. J Nurs Care [Internet]. 2015[cited 2016 Apr 4];4(125):1. Available from: http://www.omicsgroup.org/journals/editorial-communication-style-makes-a-difference-2167-11 68-1000e125.php?aid =45312

5. Berlo DK. O processo da comunicação: introdução à teoria e à pratica. 10a Ed. São Paulo: Martins Fontes; 2003.

6. King IM. A theory for nursing: systems, concepts, process. New York: John Wiley \& Sons Inc; 1981.

7. Trentini M, Paim L, Silva DMGV. Pesquisa convergente assistencial: delineamento provocador de mudança nas práticas de saúde. Porto Alegre: Moriá; 2014.

8. Rocha PK, Prado ML, Silva DMGV. Pesquisa Convergente Assistencial: uso na elaboração de modelos de cuidado de enfermagem. Rev Bras Enferm [Internet]. 2012 [cited 2016 Apr 4];65(6):1019-25. Available from: http://dx.doi.org/10.1590/ S0034-71672012000600019

9. Cavalcante RB, Calixto P, Pinheiro MMK. Análise de conteúdo: considerações gerais, relações com a pergunta de pesquisa, possibilidades e limitações do método. Inf Soc Est [Internet]. 2014 [cited 2016 Apr 4];24(1):13-8. Available from: http://www.ies. ufpb.br/ojs/index.php/ies/article/view/10000/10871

10. Vale EG, Pagliuca LMF. Construção de um conceito de cuidado de enfermagem: contribuição para o ensino de graduação. Rev Bras Enferm [Internet]. 2011 [cited 2016 Jan 16];64(1):106-13. Available from: http://dx.doi.org/10.1590/S0034-71672011000100016

11. Holler JW. Co-speech gesture mimicry in the process of collaborative referring during face-to-face dialogue. J Nonverb Behav [Internet]. 2011 [cited 2016 Jan 16];35:133-53. Available from: https://link.springer.com/article/10.1007\%2Fs10919-011-0105-6

12. Happ MB, Garrett K, Thomas DD, Tate J, George E, Houze M, et al. Nurse-patient communication interactions in the intensive care unit. Am J Crit Care[Internet]. 2011[cited 2016 Jan 16];20:e28-40. Available from: http://dx.doi.org/10.4037/ajcc2011433

13. Cloyes KG, Carpenter JG, Berry PH, Reblin M, Clayton M, Ellington L. "A True Human Interaction": comparison of family caregiver and hospice nurse perspectives on needs of family hospice caregivers. J Hospice Palliat Nurs [Internet]. 2014 [cited 2016 Jan 16];16(5):28290. Available from: http://journals.Iww.com/jhpn/Abstract/2014/07000/_A_True_Human_Interaction__Comparison_of_Family.8.aspx

14. Lanzoni GMM, Meirelles BHS. A rede de relações e interações da equipe de saúde na atenção básica e implicações para a 
enfermagem. Acta Paul Enferm [Internet]. 2012 [cited 2016 Jan 16];25(3):464-70. Available from: http://dx.doi.org/10.1590/ S0103-21002012000300023

15. Regis LFLV, Porto IS. Necessidades humanas básicas dos profissionais de enfermagem: situações de (in)satisfação no trabalho. Rev Esc Enferm USP [Internet]. 2011 [cited 2016 Jan 16];45(2):334-41. Available from: http://dx.doi.org/10.1590/S0080-62342011000200005

16. Kennedy MS. It's About the Patients. Am J Nurs [Internet]. 2013 [cited 2016 Jan 16];113(9):[1 tela]. Available from: http://journals. Iww.com/ajnonline/Fulltext/2013/09000/It_s_About_the_Patients.1.aspx 